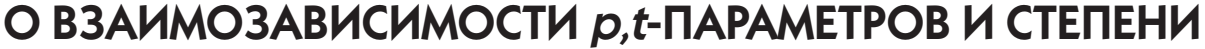 СТРУКТУРНО-ВЕЩЕСТВЕННЫХ ПРЕОБРАЗОВАНИЙ АЯЯ ФРАГМЕНТА АНЕСТРОВСКО-БУГСКОГО МЕГАБАОКА УКРАИНСКОГО ЩИТА
}

\author{
Л.С. Осьмачко ${ }^{1}$, В.А. Вильковский르, Е.О. Касьяненко ${ }^{3}$, А.А. Вишневский ${ }^{4}$ \\ (Рекомендована д-ром геол.-минерал. наук С.Г. Кривдиком) \\ ${ }^{1}$ Институт геохимии, минералогии и рудообразования им. Н.П. Семененко НАН Украины, \\ Киев, Украина, E-mail: Osml@ukr.net_ \\ Кандидат геологических наук, старший научный сотрудник. \\ ${ }^{2}$ Институт геохимии, минералогии и рудообразования им. Н.П. Семененко НАН Украинь,, \\ Киев, Украина. Научный сотрудник. \\ ${ }^{3}$ Киевский национальный университет им. Тараса Шевченко, Киев, Украина, \\ E-mail: kasya511@mail.ru Аспирант. \\ ${ }^{4}$ Институт геохимии, минералогии и рудообразования им. Н.П. Семененко НАН Украины, \\ Киев, Украина. Кандидат геолого-минералогических наук, старший научный сотрудник.
}

Применены методы структурно-парагенетического анализа с термодинамическими исследованиями. Проанализировано строение на разных иерархических уровнях Литинской и Хмельникской структур Днестровско-Бугского мегаблока Украинского щита. Прослежено распределение $p, t$-параметров составляющих их пород соответственно вариациям структурных особенностей геологических тел. Исследуемая часть мегаблока по совокупности данных интерпретирована как часть дислокационной системы вращательного сдвига, которая формировалась в несколько тектонических импульсов. $P, t$-значения образования породных ассоциаций Литинской и Хмельникской структур зависят от степени их структурно-метаморфогенных преобразований. Расчетная глубина образования гранатов из гранитоидов Днестровско-Бугского мегаблока составляет 10-23 км. P,t-значения большинства пород Литинской и Хмельникской структур расположены в области между геотермами стабильной континентальной коры и островных дуг.

Ключевые слова: структуры, гранитоиды, степень преобразований, гранат-биотитовые парагенезисы, $p, t$-параметры.

\section{ABOUT INTERDEPENDENCE OF $p, t$-PARAMETERS AND DEGREE OF STRUCTURAL-SUBSTANCEAL TRANSFORMATION FOR FRAGMENTS ON THE DNIESTER-BUG MEGABLOCK THE UKRAINIAN SHIELD}

\section{L.S. Osmachko', V.A. Vilkovsky², K.O. Kasianenko³ , A.A. Vishnevsky4 (Recommended by doctor of geological sciences S.G. Kryvdik)}

${ }^{1}$ N.P. Semenenko Institute of Geochemistry, Mineralogy and Ore Formation of NAS of Ukraine, Kiev, Ukraine, E-mail: Osml@ukr.net_Candidate of geological sciences, senior research scientist.

${ }^{2}$ N.P. Semenenko Institute of Geochemistry, Mineralogy and Ore Formation of NAS of Ukraine, Kiev, Ukraine. Researcher.

${ }^{3}$ National Taras Shevchenko University of Kiev, Kiev, Ukraine, E-mail: kasya511@mail.ru Ph. D. student.

${ }^{4}$ N.P. Semenenko Institute of Geochemistry, Mineralogy and Ore Formation of NAS of Ukraine, Kiev, Ukraine. Candidate of geological-mineralogical sciences, senior research scientist.

() Л.С. Осьмачко, В.А. Вильковский, Е.О. Касьяненко, А.А. Вишневский, 2015 
Methods of structural-paragenetic analysis and thermodynamic studies were applied. The organization of Litynska and Khmelnytska structures of the Dniester-Bug megablock of Ukrainian Shield were analysed at different hierarchical levels. The distribution of $p$, $t$-parameters of forming rocks, related to variations in the structural features of geological bodies also was analysed. Studied part of the megablock on a collection of data was interpreted as a part of shear and rotation of dislocational system, which was formed in several tectonic impulses. $P$, $t$-values of formation of rock associations of Litynska and Khmelnytska structures depend on level of their structural and metamorphic transformations. Estimated depth of garnets' formation from granitoids of the Dniester-Bug megablock is $10-23 \mathrm{~km}$. $P$, $t$-values of prevailing rocks of Litynska and Khmelnytska structures are located in the area between geoterms of prevailing rocks of Litynska and Khmelnytska structures are located in the area between geoterms of stable continental crust and island arcs. Key words: structures, granitoids, the degree of transformation, garnet-biotite parageneses, $p, t$-parameters.

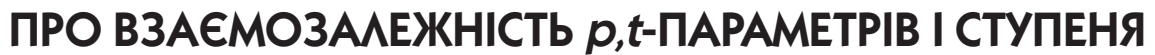 СТРУКТУРНО-РЕЧОВИННИХ ПЕРЕТВОРЕНЬ ААЯ ФРАГМЕНТУ АНІСТРОВСЬКО-БУЗЬКОГО МЕГАБАОКА УКРАЇНСЬКОГО ЩИТА}

\section{Л.С. Осьмачко ${ }^{1}$, В.О. Вільковський ${ }^{2}$, К.О. Касьяненко ${ }^{3}$, О.А. Вишневський ${ }^{4}$}

(Рекомендовано д-ром геол.-мінерал. наук С.Г. Кривдіком)

${ }^{1}$ Інститут геохімї̈, мінералогї та рудоутворення ім. М.П. Семененка НАН України, Київ, Україна, E-mail: Osml@ukr.net_Кандидат геологічних наук, старший науковий співробітник.

${ }^{2}$ Інститут геохімії, мінералогії та рудоутворення ім. М.П. Семененка НАН Украӥни, Київ, Украӥна. Науковий співробітник.

${ }^{3}$ Київський національний університет ім. Тараса Шевченка, Київ, Україна, E-mail: kasya511@mail.ru Acnipaнm.

${ }^{4}$ Інститут геохімї̈, мінералогї та рудоутворення ім. М.П. Семененка НАН Украӥни, Київ, Україна. Кандидат геолого-мінералогічних наук, старший науковий співробітник.

Застосовані методи структурно-парагенетичного аналізу з термодинамічними дослідженнями. Проаналізована будова на різних ієрархічних рівнях Літинської й Хмільницької структур Дністровсько-Бузького мегаблока Українського щита. Простежено розподіл $p, t$-параметрів порід, що їх складають, відповідно до варіацій структурних особливостей геологічних тіл. Частина мегаблока, що досліджувалася, за сукупністю даних інтерпретована як частина дислокаційної системи здвигу та ротації, яка формувалася в декілька тектонічних імпульсів. $P, t$-значення формування породних асоціацій Літинської й Хмільницької структур залежать від ступеня їх структурно-метаморфогенних перетворень. Розрахункова глибина утворення гранатів із гранітоїдів Дністровсько-Бузького мегаблока становить 10-23 км. $P, t$-значення більшості порід Літинської і Хмільницької структур містяться в області між геотермами стабільної континентальної кори та острівних дуг.

Ключові слова: структури, гранітоїди, ступінь перетворень, гранат-біотитові парагенезиси, $p, t$-параметри.

\section{Постановка проблемы}

Западная часть Украинского щита (УЩ), идентифицируемая как Днестровско-Бугский мегаблок [Рябенко, 1970; Кореляційна..., 2004; Геохронология..., 2005; Геохронология..., 2008 и др.], была задействована тектоническими преобразованиями в несколько этапов. Разные исследователи вы- деляют от четырех до восьми этапов [Рябенко, 1970; Гинтов, 2005; Державна..., 2002; Лукієнко та ін., 2008; Паталаха и др., 1995 и др.]. Как следствие, Днестровско-Бугский мегаблок является разновозрастным сооружением, в строении которого выделяются субкольцевые куполоподобные структуры второго порядка (Литинская, Липовецкая, 
Шаргородская и др.) и линейные трогоподобные (синклинальные). Эти структуры хорошо прослеживаются по характеру гравитационного и магнитного полей, по своеобразию складчатых дислокаций, по комплексам пород и условиям их метаморфизма [Рябенко, 1970; Кореляційна..., 2004; Геохронология..., 2005; Геохронология..., 2008; Державна..., 2002 и др.]. Становление межкупольных синклиналей и куполовидных образований относительно последовательности, тех или иных процессов формирования, $p, t$-условий и других характеристик трактуется исследователями неоднозначно. В связи с этим объектом изучения были Литинская куполовидная и Хмельникская линейная (синклинальная) структуры (структуры макроуровня, по [Лукієнко та ін., 2008]) Днестровско-Бугского мегаблока.

\section{Краткий обзор достижений предшественников}

В работе [Державна..., 2002] в северной части Днестровско-Бугского мегаблока выделяются структурно-вещественные комплексы (СВК) «первісної консолідації земної кори» и «колізійний». В состав первого СВК входят две формации: палеоархейская гранулит-базитовая (березнинская, тывровская толщи) и неоархейская эндербит-плагиомигматитовая (литинский ультраметаморфический комплекс). Второй СВК включает палеопротерозойские плагиогранит-мигматитовую и гранит-мигматитовую (обе относятся к бердичевскому комплексу), мезопротерозойскую гранитовую (хмельникский комплекс), а также дайковую. Зоны перехода между породами формаций к гранулитовым образованиям субсогласные, реакционные с развитием промежуточных образований гранодиоритов (собитов) и винницитов [Державна..., 2002 и др.]. СВК первичной консолидации литосферы в современном срезе исследуемого фрагмента УЩ выражен в виде геологических тел разнообразных размеров (от нескольких до первых десятков километров), линзовидных, субкольцевых и неправильных форм, которые неравномерно распределены по площади. Они соответствуют «фемическим» магнитным блокам с крутопадающими ограничениями и утолщенной корой, которые прослеживаются на большие глубины [Державна..., 2002; Крути- ховская и др., 1983 и др.]. Для субкольцевых (купольных) тел характерно пологое падение крыльев, чаще под углами 20-30 [Державна..., 2002; Рябенко, 1970 и др.]. Коллизионный СВК также выражен в виде геологических тел разнообразных размеров (от нескольких до первых десятков километров), субкольцевых, неправильных, но в основном линзовидных и линейных форм, которые заполняют большую часть исследуемой площади [Державна..., 2002; Геологическая..., 1983 и др.]. Для линзовидно-линейных тел характерно крутое падение полосчатости более $60^{\circ}$. Такие образования преимущественно тяготеют к немагнитным "салическим» блокам, но нередко встречаются и в пределах региональных магнитных аномалий (PМА) [Державна..., 2002; Крутиховская и др., 1983 и др.]. Изучаемые нами Литинская куполовидная структура сформирована СВК первичной консолидации земной коры, линейная Хмельникская структура - коллизионным СВК.

Литинская куполовидная (субкольцевая) структура в поперечнике достигает 30 км. В ее пределах фиксируется [Геологическая..., 1983; Рябенко, 1970; Державна..., 2002 и др.] линейная складчатость третьего и более высоких порядков, ориентированная параллельно и перпендикулярно к контурам структуры, концентрически окружая ее. Ширина складок достигает 0,7 км. Их крылья имеют крутое падение - 60-65 . Погружение шарниров непостоянно.

Для породных ассоциаций Литинской структуры (эндербиты, чарнокиты и др., относимые к литинскому комплексу, гранитоиды бердичевского комплекса) известен широкий диапазон возраста: от 3,61 до 2,0 млрд лет [Степанюк, 2000; Геохронология..., 2005; Кореляційна..., 2004 и др.]. По данным работы [Щербаков, 2005], температуры формирования чарнокитоидов литинского комплекса составляют $760-820^{\circ} \mathrm{C}$, давление 430 МПа, уровень эрозионного среза - 16 км.

Хмельникская линейная структура, согласно [Геологическая..., 1983; Гинтов, 2005; Паталаха и др., 1995], - это зона разломов северо-западного простирания; по [Рябенко, 1970] - Гниванская синклиналь, имеет протяженность 350 км и ширину около 8 км. Соответственно [Паталаха и др., 1995; Лукієнко та ін., 2008], Хмельникская 
зона разломов представляет собой мощный линеамент линзовидно-чешуйчатого строения с крутым залеганием. Линзы и чешуи выступают в роли тел-композитов разной степени дислоцированных пород. Зона сформирована структурно-вещественными комплексами катазоны (гранулитовая и амфиболитовая фации), мезозоны и эпизоны. Каждый из последующих комплексов наложен на каждый из предыдущих.

Для Хмельникской структуры характерен пестрый набор пород разного состава, строения и глубины формирования: гранатбиотитовые граниты, гиперстен-биотит-гранатовые мигматиты, чарнокиты, эндербиты, лейкократовые голубокварцевые граниты [Державна..., 2002; Степанюк, 2000; Щербаков, 2005 и др.], относимые к бердичевскому комплексу, а также лейкограниты хмельникского комлекса. Возраст (по Rb-Sr, Sm-Nd и U-Pb методам) для всех типов пород колеблется в пределах 2,7-1,9 млрд лет [Геохронология..., 2005; Геохронология..., 2008; Державна..., 2002; Степанюк, 2000; Щербаков, 2005; Кореляційна..., 2004 и др.]. $P, t$-условия образования бердичевских гранитоидов находятся в таких пределах: $t=580-850{ }^{\circ} \mathrm{C}, p=3-10$ кбар [Курепин, 1993; Степанюк, 2000; Щербаков, 2005 и др.].

Фактически все разновидности гранитоидов как Литинской, так и Хмельникской структур содержат многочисленные включения (ксенолиты) в основном линзовидных форм, разнообразных размеров - от нескольких сантиметров до первых километров. Они размещены согласно текстурным неоднородностям и ограничениям тел гранитоидов. Вещественно включения представлены преимущественно биотит- и гиперстен-гранатовыми плагиогнейсами, эндербитами, а также пироксеновыми, амфибол-двупироксеновыми кристаллическими сланцами, кальцифирами и известково-силикатными кристаллическими сланцами [Державна..., 2002; Степанюк, 2000; Щербаков, 2005 и др.].

Несмотря на глубокую и разностороннюю изученность Литинской и Хмельникской структур, нераскрытыми полностью остаются закономерности их петроструктурной организации, проливающие свет на условия становления изучаемого фрагмента УЩ
Цель нашей работы - выявление связи между особенностями строения (степенью тектонических преобразований) породных ассоциаций Литинской и Хмельникской структур и p,t-условиями их формирования.

В работе применены методы структурнопарагенетического анализа в совокупности с термодинамическими расчетами. Анализ базируется на парагенетической основе, с учетом $p, t$-условий геологических сред и характера их деформации при воздействии тектонических напряжений [Лукієнко та ін., 2008; Паталаха и др., 1995].

Инструментальные исследования минеральных пар (Gt-Bt), которые использованы для определения p,t-параметров, были проведены в ИГМР им. Н.П. Семененко НАН Украины на растровом электронном микроскопе JSM-6700F, с энергодисперсионной системой для микроанализа JED-2003 («JEOL», Япония). Для определения p-t-параметров авторы применили гранат-биотитовый термометр. Расчеты проведены с помощью таких систем термодинамических данных, как Termocalc, TWLQ, grt-bt.xls, garnet-biotite.xls.

\section{Изложение материала исследований}

Нами ранее [Осьмачко, Касьяненко, 2014; Осьмачко и др., 2014] установлено, что в пределах исследуемого фрагмента кристаллического основания развиты метамофогенно-дислокационные образования четырех генераций. Это структуры (микрои мезоструктуры [Лукієнко та ін., 2008]) разлинзования, полосчатость вторичного расслоения и гранитизации (порфиробластеза), сланцеватость и др. Структуры каждого последующего этапа в разной мере затушевывают структуры каждого предыдущего этапа, развиваясь за счет их вещества. При этом строение субкольцевой Литинской и линейной Хмельникской структур макроуровня подобно, что обусловлено фактически одинаковым пространственным размещением идентифицированных микро- и мезоструктур, количеством их генераций и взаимоотношениями (последовательным формированием). Известные различия в петроструктурной организации между данными макроструктурами кроются в разной степени преобразований (тектонофациальными (ТФ) характеристиками, по [Лукієнко 
та ін., 2008; Паталаха и др., 1995]) кристаллического основания, по которому они образовывались, на время формирования микро- и мезоструктур главным образом генераций-2, -3, а также -4. В пределах линейной Хмельникской структуры она выше [Осьмачко, Касьяненко, 2014; Осьмачко и др., 2014]. Мы акцентируем внимание на дислокационных образованиях генераций-2 и -3 потому, что именно они формируют генеральный структурный рисунок исследуемой территории, развиваясь по более древнему основанию, будучи относительно слабо задействованными преобразованиями этапа-4. Последовательное наложение структур нескольких генераций, обуславливающее перекрестное строение исследуемых фрагментов фундамента, несет и суммарную (четырехкратную) ТФ нагрузку, которую мы интерпретируем как тектоноформации.

Выявленные нами отличия в петроструктурной организации субкольцевой Литинской и линейной Хмельникской структур указывают на то, что, формируясь одновременно, первая из них является менее преобразованной/дислоцированной частью фундамента, вторая - более преобразованной. Подобный парагенезис может реализоваться только при проявлении разных геодинамических (кинематических) условий в изучаемых участках фундамента в одни и те же временные отметины. А именно - транстенсии с элементами ротации для участка, соответствующего Литинской структуре, и транспрессии для участка Хмельникской. Опираясь на имеющиеся данные и достижения предшественников [Рябенко, 1970; Лукієнко та ін., 2008; Паталаха и др., 1995; Слензак, 1984], нами определено [Осьмачко, Касьяненко, 2014; Осьмачко и др., 2014], что структурный ансамбль изучаемой части ДнестровскоБугского мегаблока УЩ соответствует дислокационной системе вращательного сдвига. Становление данной дислокационной системы происходило в несколько импульсов в $p, t$-условиях образования вещества формируемых ею тел. Каждый импульс сдвигавращения как для линейных, так и для краевых сегментов кольцевых составляющих системы сопровождался образованием новых породных тел. Окончательное оформление исследуемого фрагмента УЩ, по данным предшественников, фиксируется изотопным возрастом в 2,0-1,9 млрд лет.

Из сказанного следует, что и состав (на породном, минеральном и более высоких уровнях) геологических тел, формирующих данную дислокационную систему, должен варьировать соответственно интенсивности и динамике тектонических импульсов на время становления пород того или иного временного диапазона. А отсюда, и $p, t$-параметры образования гранатов, биотитов и других минералов должны быть соподчинены отмеченным геологическим явлениям и структурному узору территории. В связи с этим нами отобраны гранат-биотитсодержащие ассоциации из пород Литинской (г. Литин) и Хмельникской (с. Стрижавка) структур. Для обеих структур это гранатбиотитовые гранитоиды с пироксеном, относимые к бердичевскому комплексу [Кореляційна..., 2004; Щербаков, 2005; Геохронология..., 2008 и др.]. Они разнятся между собой процентным содержанием минералов и степенью рассланцевания. Исходя из этого, изучаемые гранитоиды Литинской структуры идентифицированы как собственно виннициты; Хмельникской структуры - как меланократовые и лейкократовые гранитоиды с гранатом и пироксеном.

Для всех разновидностей пород пространственное размещение гранатов соподчинено структурам генерации-2 - полосчатости и сланцеватости северо-западного простирания с крутой линейностью, а точнее, они вместе с породообразующими минералами формируют сланцеватость пород. Сланцеватость отображена односистемной ориентацией и вытянутостью всех минералов и их агрегатов. При этом в них наблюдаются следы перекристаллизации и замещения. Последние в шлифах проявлены зональным, неоднородным строением большинства минералов. Соподчиненность размещения гранатов сланцеватости выражена тем, что на микроучастках слабо или не вовлеченных в рассланцевание этапа-2 гранаты, как и другие минералы, суб-, идиоморфны. На участках пород, задействованных рассланцеванием этого этапа, гранаты, как и породообразующие минералы, имеют линзовидные формы до разобщения их на отдельные фрагменты 
(рис. 1), а также четкообразные S- и б-подобные конфигурации. Кроме того, на этих участках гранаты вместе с биотитом (главным образом в меланократовых гранитои- дах), а также вместе с кварцем и биотитом, иногда с калиевым полевым шпатом (КПШ) (преимущественно в лейкократовых гранитоидах) формируют линзовидные агрегаты.

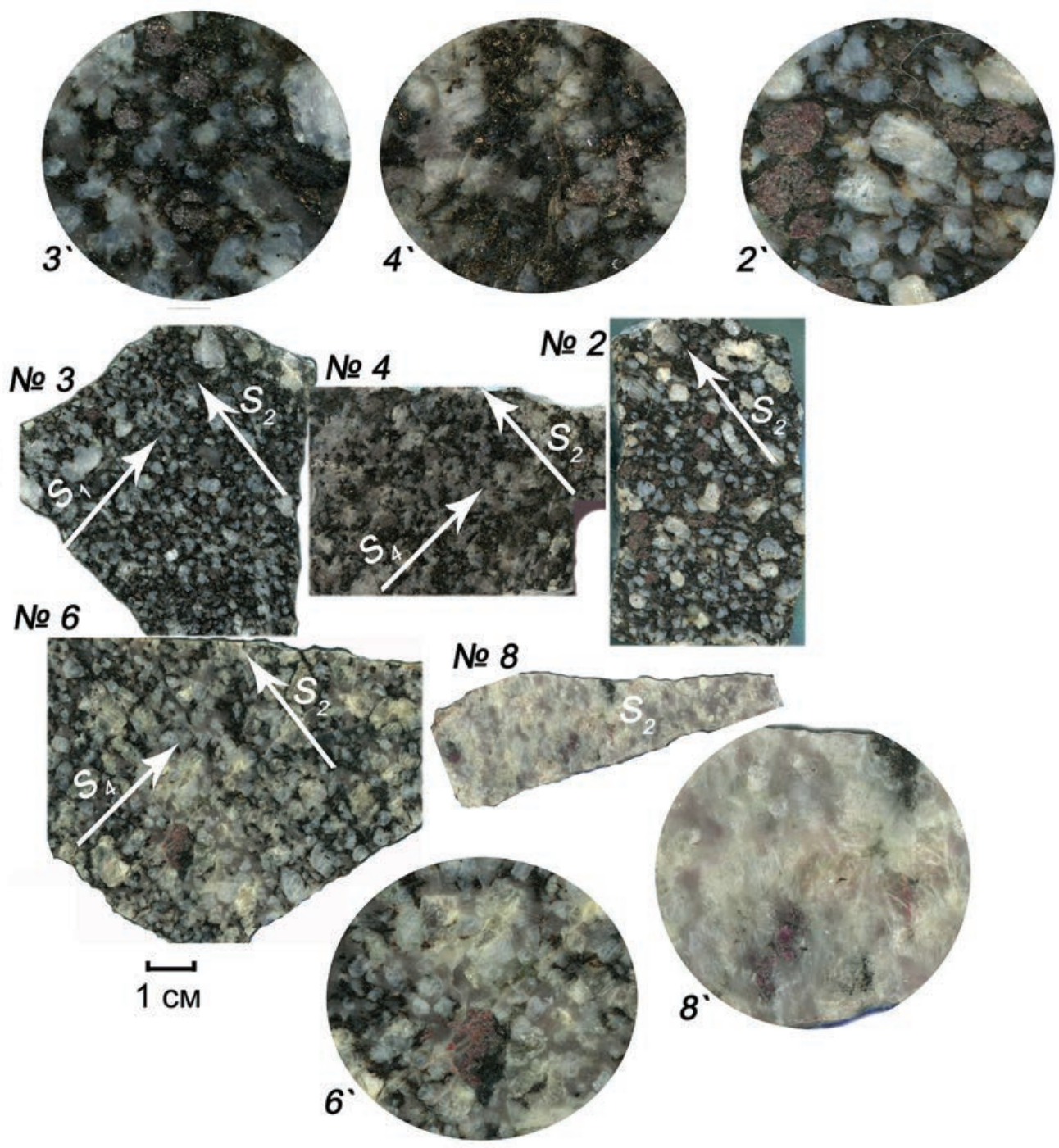

Рис. 1. Строение породных разновидностей из участка кристаллического фундамента в пределах Хмельникской зоны разломов (у с. Стрижавка)

№ 2-4 - меланократовые гранитоиды, в последовательности увеличения степени рассланцевания для структур генерации-2; № 6, 8 - лейкократовые гранитоиды, в той же последовательности; 2' -8' - соответственно увеличенные их фрагменты (примерно в 3 раза). № соответствует таковым в тексте и таблицах. На увеличенных фрагментах отображены зерна гранатов, задействованных рассланцеванием северо-западного простирания $\left(\mathrm{S}_{2}\right)$. На $6^{\prime}$ - зерно дважды вовлечено в рассланцевание $-S_{2}$ и $S_{4}$. Подобные индикаторы становления пород при смещении отмечены для всех изучаемых разновидностей пород. Стрелки - ориентировка структур. 1-4 - № генерации структур. Срезы образцов в плоскости а/с, по [Лукієнко та ін., 2008]

Fig. 1. Structure of varieties rocks on area of the crystalline basement within Khmelnytska fault zone (s. Strizhavka)

№ 2-4 - melanocratic granitoids, in the sequence of increasing the degree of shearing for structures generation-2; № 6, 8 leucocratic granitoids, in the same sequence; $2^{\prime}-8^{\prime}-$ respectively, enlarged fragments ( three times). № correspond to those in the text and tables. Larger fragments displayed grains garnets involved shearing northwest trending $\left(\mathrm{S}_{2}\right) .6^{\circ}-$ grain twice involved in foliation $-\mathrm{S}_{2}$ and $\mathrm{S}_{4}$. Such indicators formation rocks marked the displacement for all studied rocks. Arrows - the orientation of the structures. 1-4 - № generation of structures. Slices of a sample in the plane a/c, to [Лукіенко та ін., 2008] 
По данным работ [Горяйнов и др., 2003; Лукієнко та ін., 2008; Паталаха и др., 1995; Слензак, 1984 и др.], отмеченные нами агрегаты формируются вследствие компенсационной/синдеформационной перекристаллизации в процессе смещения и вращения при действии деформаций сдвига. На рис. 1 для обр. 6 видно, что линзовидный агрегат состава гранат - кварц - полевой шпат дважды задействован рассланцеванием (синдеформационной перекристаллизацией). Сначала рассланцеванием этапа-2, что выражено в пространственном размещении линзы; потом - рассланцеванием этапа-4, что выявлено в образовании и соответствующем размещении хвостов сдвига (нарастания). Такое участие гранатов в формировании структурного рисунка породы свидетельствует о том, что они формировались до рассланцевания этапа2, отдельные индивиды или их фрагменты могли образоваться во время данных трансформаций. Отмеченное свидетельствует, что обнаруженные нами гранаты отображают $p, t$-параметры 1- и 2-го этапов становления исследуемых пород, а не их окончательного формирования. По данным [Горяйнов и др., 2003], структуры 1-, 2-й генераций имеют архейский возраст.

Нами определен химический состав альмандинов и даны их кристаллохимические формулы, рассчитанные на 12 атомов кислорода (табл. 1, 2). Рассмотрим подробнее изменение состава граната от $p, t$-условий. Альмандин является одним из главных компонентов метаморфических гранатов (табл. 1, 2). Пироповый минал - хороший индикатор вариаций температур и давлений.

Таблица 1. Химический состав (в вес. \%) альмандинов из гранитоидов Литинской структуры

Table 1. Chemical composition (wt. \%) almandine of granitoids of the Litynska structure

\begin{tabular}{|c|c|c|c|c|c|c|c|c|c|c|}
\hline № обр. & Л-8-1 & л-8-2 & Л-8-11 & Л-8-13 & Л-8-14 & л-7-69 & Л-7-55 & л-7-50 & л-7-52 & Л-7-54 \\
\hline $\mathrm{SiO}_{2}$ & 38,74 & 38,85 & 38,72 & 38,61 & 38,50 & 39,32 & 39,21 & 39,01 & 38,69 & 38,81 \\
\hline $\mathrm{TiO}_{2}$ & 0,03 & 0,09 & 0,13 & 0,08 & 0,06 & 0,00 & 0,00 & 0,01 & 0,00 & 0,00 \\
\hline $\mathrm{Al}_{2} \mathrm{O}_{3}$ & 21,33 & 22,45 & 21,70 & 21,30 & 21,73 & 22,69 & 22,78 & 21,68 & 22,29 & 22,40 \\
\hline$\Sigma \mathrm{FeO}$ & 31,77 & 30,51 & 30,94 & 30,69 & 30,98 & 29,47 & 29,35 & 30,28 & 29,66 & 30,26 \\
\hline $\mathrm{MnO}$ & 0,25 & 0,15 & 0,05 & 0,26 & 0,06 & 0,22 & 0,00 & 0,00 & 0,34 & 0,08 \\
\hline $\mathrm{MgO}$ & 6,51 & 6,69 & 6,68 & 6,82 & 7,10 & 7,32 & 7,75 & 7,68 & 7,95 & 7,50 \\
\hline $\mathrm{CaO}$ & 1,32 & 1,17 & 1,24 & 1,65 & 1,39 & 0,79 & 0,86 & 0,84 & 0,68 & 0,80 \\
\hline $\mathrm{Na}_{2} \mathrm{O}$ & 0,00 & 0,03 & 0,31 & 0,46 & 0,00 & 0,15 & 0,04 & 0,22 & 0,30 & 0,16 \\
\hline $\mathrm{K}_{2} \mathrm{O}$ & 0,03 & 0,00 & 0,07 & 0,09 & 0,02 & 0,01 & 0,00 & 0,01 & 0,05 & 0,00 \\
\hline$\Sigma \Sigma$ & 99,9 & 100,00 & 99,9 & 100,00 & 99,99 & 100,01 & 99,99 & 101,49 & 99,99 & 100,01 \\
\hline $\mathrm{Si}$ & 3,03 & 3,02 & 3,02 & 3,02 & 3,01 & 3,03 & 3,02 & 3,03 & 3,00 & 3,01 \\
\hline $\mathrm{Ti}$ & 0,00 & 0,01 & 0,01 & 0,00 & 0,00 & 0,00 & 0,00 & 0,00 & 0,00 & 0,00 \\
\hline $\mathrm{Al}$ & 1,97 & 2 & 2 & 1,96 & 2 & 2 & 2,07 & 1,98 & 2 & 2 \\
\hline$\Sigma \mathrm{Fe}$ & 2,08 & 1,98 & 2,02 & 2,01 & 2,02 & 1,90 & 1,89 & 1,97 & 1,92 & 1,96 \\
\hline $\mathrm{Mn}$ & 0,02 & 0,01 & 0,01 & 0,02 & 0,01 & 0,01 & 0,01 & 0,01 & 0,02 & 0,01 \\
\hline $\mathrm{Mg}$ & 0,76 & 0,77 & 0,78 & 0,80 & 0,83 & 0,84 & 0,89 & 0,89 & 0,92 & 0,87 \\
\hline $\mathrm{Ca}$ & 0,11 & 0,10 & 0,10 & 0,14 & 0,12 & 0,07 & 0,07 & 0,07 & 0,06 & 0,07 \\
\hline $\mathrm{Na}$ & 0,00 & 0,00 & 0,05 & 0,07 & 0,00 & 0,02 & 0,01 & 0,03 & 0,05 & 0,02 \\
\hline $\mathrm{K}$ & 0,00 & 0,00 & 0,01 & 0,01 & 0,00 & 0,00 & 0,00 & 0,00 & 0,00 & 0,00 \\
\hline$\Sigma$ & 8,1 & 8,2 & 8,11 & 8,13 & 8,14 & 7,69 & 7,55 & 7,50 & 7,52 & 7,54 \\
\hline Pir & 26 & 27 & 27 & 27 & 27 & 30 & 31 & 30 & 32 & 30 \\
\hline Alm & 70 & 69,2 & 70 & 68 & 68 & 67 & 66 & 67 & 66 & 67 \\
\hline Sps & 0,7 & 0,4 & 0,1 & 0,7 & 0,1 & 0,4 & 0,04 & 0,03 & 0,7 & 0,3 \\
\hline Gros & 3,7 & 3,5 & 3,3 & 4,3 & 4 & 2,5 & 2,7 & 2,7 & 2 & 2,7 \\
\hline
\end{tabular}


Таблица 2. Химический состав (в вес. \%) альмандинов из гранитоидов Хмельникской структуры

Table 2. Chemical composition (wt. \%) of almandine granitoids of the Khmelnytska structure

\begin{tabular}{|c|c|c|c|c|c|c|c|c|c|c|c|c|c|}
\hline № обр, & $2-94$ & $2-97$ & $2-98$ & $2-125$ & $3-69$ & $3-70$ & 4-128 & $4-130$ & 4-131 & $4-132$ & $4-133$ & 4-134 & 4-135 \\
\hline $\mathrm{SiO}_{2}$ & 37,97 & 37,54 & 38,32 & 37,56 & 37,53 & 37,9 & 37,55 & 38,09 & 37,03 & 36,85 & 37,28 & 37,33 & 37,35 \\
\hline $\mathrm{TiO}_{2}$ & 0 & 0,18 & 0,07 & 0,02 & 0,15 & 0,29 & 0,09 & 0 & 0,14 & 0,03 & 0,13 & 0 & 0,09 \\
\hline $\mathrm{Al}_{2} \mathrm{O}_{3}$ & 20,86 & 20,72 & 20,95 & 20,81 & 20,2 & 20,19 & 20,43 & 20,36 & 19,76 & 20,28 & 20,33 & 19,72 & 20,01 \\
\hline$\sum \mathrm{FeO}$ & 34,53 & 34,6 & 34,26 & 35,04 & 35,95 & 35,37 & 33,87 & 34,33 & 35,02 & 34,87 & 34,69 & 35,29 & 35,15 \\
\hline $\mathrm{MnO}$ & 0,52 & 0,48 & 0,54 & 0,71 & 0,47 & 0,51 & 2,03 & 1,65 & 2,08 & 2,28 & 1,33 & 2,1 & 1,81 \\
\hline $\mathrm{MgO}$ & 3,74 & 3,92 & 3,77 & 4,17 & 4,18 & 4,13 & 3,02 & 2,63 & 3,11 & 2,49 & 3,11 & 2,83 & 2,9 \\
\hline $\mathrm{CaO}$ & 1,98 & 1,88 & 1,91 & 1,29 & 1,11 & 1,34 & 2,45 & 2,42 & 2,02 & 2,32 & 2,13 & 2,34 & 2,3 \\
\hline $\mathrm{Na}_{2} \mathrm{O}$ & 0,37 & 0,48 & 0,08 & 0,28 & 0,36 & 0,17 & 0,52 & 0,4 & 0,71 & 0,77 & 0,16 & 0,37 & 0,27 \\
\hline $\mathrm{K}_{2} \mathrm{O}$ & 0,01 & 0,14 & 0,11 & 0,08 & 0,05 & 0,07 & 0,07 & 0,11 & 0,04 & 0,1 & 0,15 & 0,02 & 0,13 \\
\hline$\Sigma$ & 99,98 & 99,94 & 100,01 & 99,96 & 100 & 99,97 & 100,03 & 99,99 & 100,11 & 99,99 & 99,41 & 100 & 100,01 \\
\hline $\mathrm{Si}$ & 3,04 & 3,01 & 3,05 & 3 & 3,02 & 3,04 & 3,02 & 3,06 & 3 & 3 & 3,03 & 3,03 & 3,02 \\
\hline $\mathrm{Ti}$ & 0 & 0,01 & 0,004 & 0,001 & 0,009 & 0,017 & 0,005 & 0 & 0,008 & 0,001 & 0,008 & 0 & 0,005 \\
\hline $\mathrm{Al}$ & 1,96 & 1,96 & 1,97 & 1,97 & 1,94 & 1,91 & 1,94 & 1,93 & 1,89 & 1,94 & 1,94 & 1,89 & 1,91 \\
\hline $\mathrm{Fe}$ & 2,31 & 2,32 & 2,28 & 2,35 & 2,42 & 2,37 & 2,28 & 2,31 & 2,38 & 2,37 & 2,35 & 2,39 & 2,38 \\
\hline $\mathrm{Mn}$ & 0,035 & 0,03 & 0,036 & 0,048 & 0,03 & 0,035 & 0,14 & 0,11 & 0,16 & 0,16 & 0,09 & 0,14 & 0,12 \\
\hline $\mathrm{Mg}$ & 0,45 & 0,47 & 0,45 & 0,5 & 0,5 & 0,49 & 0,36 & 0,32 & 0,38 & 0,3 & 0,38 & 0,34 & 0,35 \\
\hline $\mathrm{Ca}$ & 0,17 & 0,16 & 0,16 & 0,11 & 0,095 & 0,12 & 0,21 & 0,21 & 0,18 & 0,2 & 0,18 & 0,2 & 0,2 \\
\hline $\mathrm{Na}$ & 0,05 & 0,05 & 0,01 & 0,04 & 0,056 & 0,026 & 0,08 & 0,06 & 0,11 & 0,12 & 0,025 & 0,06 & 0,04 \\
\hline $\mathrm{K}$ & 0,001 & 0,001 & 0,011 & 0,008 & 0,005 & 0,007 & 0,07 & 0,011 & 0,004 & 0,01 & 0,015 & 0,002 & 0,01 \\
\hline$\Sigma$ & 8,016 & 8,171 & 7,97 & 8,027 & 8,075 & 8,015 & 8,042 & 8,01 & 8,112 & 8,101 & 8,018 & 8,052 & 8,035 \\
\hline Pir & 0,15 & 0,16 & 0,15 & 0,17 & 0,16 & 0,16 & 0,12 & 0,11 & 0,12 & 0,099 & 0,13 & 0,11 & 0,11 \\
\hline Alm & 0,78 & 0,78 & 0,78 & 0,78 & 0,79 & 0,78 & 0,76 & 0,78 & 0,77 & 0,78 & 0,78 & 0,78 & 0,78 \\
\hline Sps & 0,012 & 0,01 & 0,012 & 0,016 & 0,009 & 0,012 & 0,047 & 0,037 & 0,052 & 0,053 & 0,03 & 0,046 & 0,039 \\
\hline Gros & 0,057 & 0,05 & 0,05 & 0,037 & 0,031 & 0,039 & 0,07 & 0,07 & 0,058 & 0,066 & 0,06 & 0,065 & 0,062 \\
\hline № обр, & 4-146 & 4-147 & 6-1 & $6-2$ & 6-3 & 6-4 & 6-12 & $6-13$ & 6-14 & $6-15$ & $8-27$ & $8-28$ & \\
\hline $\mathrm{SiO}_{2}$ & 37,64 & 37,84 & 37,76 & 38,36 & 38,47 & 38,18 & 37,81 & 38,05 & 37,9 & 38 & 38,69 & 38,69 & \\
\hline $\mathrm{TiO}_{2}$ & 0 & 0,17 & 0 & 0 & 0 & 0,09 & 0,04 & 0,03 & 0,03 & 0 & 0,08 & 0,01 & \\
\hline $\mathrm{Al}_{2} \mathrm{O}_{3}$ & 20,47 & 20,12 & 21,27 & 21,17 & 20,31 & 20,82 & 21,04 & 20,63 & 20,89 & 20,66 & 20,63 & 20,79 & \\
\hline$\sum \mathrm{FeO}$ & 34,63 & 34,36 & 34,11 & 33,7 & 34,74 & 35,11 & 33,69 & 33,83 & 34,36 & 34,28 & 32,33 & 32, & \\
\hline $\mathrm{MnO}$ & 1,29 & 0,99 & 0,62 & 0,84 & 0,82 & 0,94 & 1,08 & 0,86 & 0,82 & 1 & 0,39 & 0,3 & \\
\hline $\mathrm{MgO}$ & 3,44 & 3,28 & 4,52 & 4,28 & 3,91 & 3,27 & 4,51 & 4,76 & 4,46 & 4,43 & 6,15 & 6,74 & \\
\hline $\mathrm{CaO}$ & 2,15 & 2,59 & 1,36 & 1,49 & 1,44 & 1,59 & 1,3 & 1,5 & 1,43 & 1,43 & 1,39 & 1,18 & \\
\hline $\mathrm{Na}_{2} \mathrm{O}$ & 0,37 & 0,52 & 0,31 & 0,17 & 0,22 & 0 & 0,43 & 0,27 & 0,04 & 0,21 & 0,39 & 0,17 & \\
\hline $\mathrm{K}_{2} \mathrm{O}$ & 0 & 0,13 & 0,05 & 0 & 0,08 & 0,01 & 0,1 & 0,006 & 0,06 & 0 & 0,03 & 0,11 & \\
\hline$\Sigma$ & 99,99 & 100 & 100 & 100,01 & 99,99 & 100,01 & 100 & 99,95 & 100 & 100,01 & 100,08 & 99,99 & \\
\hline $\mathrm{Si}$ & 3,02 & 3,04 & 3,01 & 3,05 & 3,08 & 3,05 & 3,01 & 3,03 & 3,02 & 3,03 & 3,05 & 3,04 & \\
\hline $\mathrm{Ti}$ & 0 & 0,01 & 0 & 0 & 0 & 0,005 & 0,002 & 0,002 & 0,002 & 0 & 0,005 & 0,001 & \\
\hline $\mathrm{Al}$ & 1,94 & 1,91 & 2 & 1,98 & 1,92 & 1,96 & 1,97 & 1,94 & 1,96 & 1,94 & 1,91 & 1,92 & \\
\hline $\mathrm{Fe}$ & 2,33 & 2,31 & 2,28 & 2,24 & 2,32 & 2,35 & 2,25 & 2,25 & 2,29 & 2,29 & 2,13 & 2,1 & \\
\hline $\mathrm{Mn}$ & 0,087 & 0,067 & 0,04 & 0,05 & 0,05 & 0,06 & 0,07 & 0,056 & 0,055 & 0,067 & 0,03 & 0,019 & \\
\hline $\mathrm{Mg}$ & 0,41 & 0,39 & 0,54 & 0,51 & 0,46 & 0,39 & 0,54 & 0,57 & 0,53 & 0,53 & 0,72 & 0,79 & \\
\hline $\mathrm{Ca}$ & 0,19 & 0,22 & 0,12 & 0,12 & 0,12 & 0,14 & 0,11 & 0,13 & 0,12 & 0,12 & 0,12 & 0,099 & \\
\hline $\mathrm{Na}$ & 0,06 & 0,08 & 0 & 0 & 0 & 0 , & 0,07 & 0,04 & 0,006 & 0,03 & 0,05 & 0,026 & \\
\hline $\mathrm{K}$ & 0 & 0,01 & 0,005 & 0 & 0 & 0,001 & 0,01 & 0,001 & 0,006 & 0 & 0,003 & 0,011 & \\
\hline$\Sigma$ & 8,037 & 100 & 7,995 & 7,95 & 7,95 & 7,956 & 8,03 & 8,019 & 7,989 & 8,007 & 8,018 & 8,006 & \\
\hline Pir & 0,14 & 0,13 & 0,18 & 0,17 & 0,16 & 0,13 & 0,18 & 0,19 & 0,18 & 0,18 & 0,24 & 0,26 & \\
\hline Alm & 0,77 & 0,77 & 0,77 & 0,77 & 0,79 & 0,8 & 0,76 & 0,75 & 0,76 & 0,76 & 0,71 & 0,7 & \\
\hline Sps & 0,029 & 0,022 & 0,013 & 0,017 & 0,017 & 0,02 & 0,024 & 0,019 & 0,018 & 0,022 & 0,01 & 0,007 & \\
\hline Gros & 0,063 & 0,074 & 0,04 & 0,064 & 0,04 & 0,05 & 0,037 & 0,043 & 0,04 & 0,035 & 0,04 & 0,062 & \\
\hline
\end{tabular}


Увеличение пиропового компонента отражает повышение температуры и (или) давления. Известно, что содержание пиропа в метаморфических гранатах редко достигает 40-50\%, да и то только в условиях высоких температур и давлений при метаморфизме. Для низко- и среднетемпературных условий метаморфизма характерны низкие содержания $\mathrm{MgO}$, не превышающее, как правило, 3-4\%. Содержание $\mathrm{MgO}$ в альмандинах изменяется от 2,49 до 6,74\% для Хмельникской структуры и от 0,56 до 7,75\% для Литинской (табл. 1, 2). Пиропсоставляющая в альмандинах Хмельникской зоны колеблется от 15 до 25\%, в Литинской - от 25 до 32\%. Богатые спессартином гранаты (15-25\% MnO) наиболее характерны для низкотемпературных фаций метаморфизма. Тогда как в альмандинах Хмельникской зоны наибольшее содержание спессартина достигает от 0,7 до 5,3\%, в Литинской структуре - от 0,03 до 0,7\%.

На основании использования комплекса методов [Перчук, 1967; Колесник и др., 1988] нами получены следующие $p, t$-параметры образования гранатов (табл. 3). В табл. 3 и на рис. 2 породы сгруппированы по относительному возрасту (в основу данной

Таблица 3. $P$, $t$-параметры образования гранатов из гранитоидов Литинской и Хмельникской структур в зависимости от степени структурно-метаморфогенных преобразований пород

Table 3. $P, t$-parameters of the formation of garnet of the granitoids Litynska and Khmelnytska structures depending on the degree of structural and metamorphic rock transformations

\begin{tabular}{|c|c|c|c|c|c|c|c|}
\hline Структура макроуровня & \multicolumn{2}{|c|}{ Литинская } & \multicolumn{5}{c|}{ Хмельникская } \\
\hline Название породы & \multicolumn{2}{|c|}{ Винницит } & \multicolumn{2}{|c|}{ Меланократовый гранитоид } & \multicolumn{2}{|c|}{ Лейкократовый гранитоид } \\
\hline ТФР* & \multicolumn{2}{|c|}{ Низкая } & \multicolumn{3}{|c|}{ Средяя } & \multicolumn{2}{|c|}{ Высокая } \\
\hline ТФ** & Средняя & Высокая & Низкая & Средняя & Высокая & Средняя & Высокая \\
\hline$t,{ }^{\circ} \mathrm{C}$ & $610-640$ & $620-640$ & $550-600$ & $530-580$ & $530-580$ & $480-530$ & $550-600$ \\
\hline$p$, кбар & $4-6$ & $4-6$ & $5,2-7,5$ & $4,5-6,1$ & $4,5-6,1$ & $3-4,5$ & $5,2-7,5$ \\
\hline
\end{tabular}

* Степень преобразований для дислокационной системы - тектоноформации.

** Степень преобразований для типа пород - группы тектонофаций, по [Лукієнко та ін., 2008].

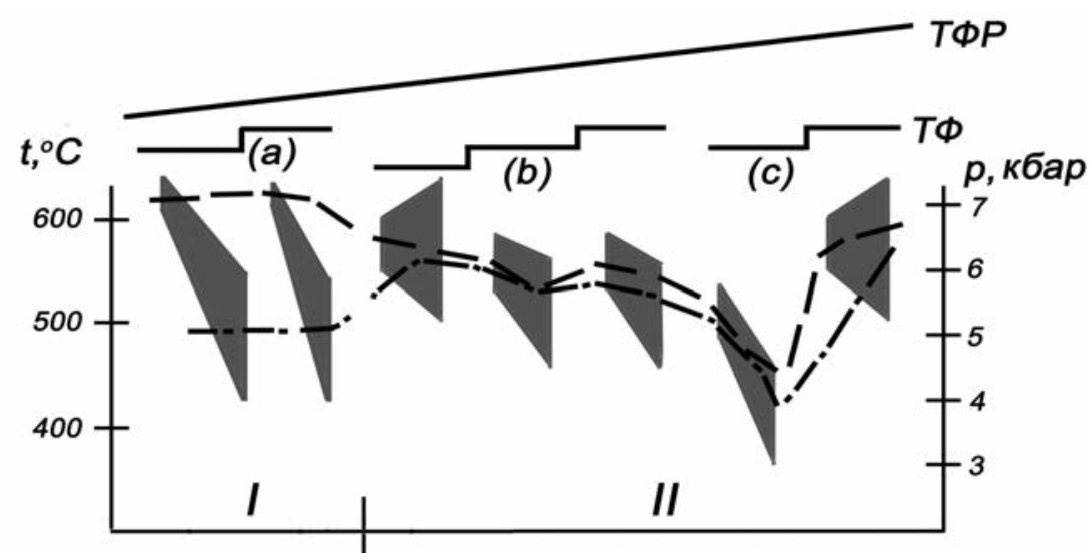

Рис. 2. Р,t-значения образования гранатов из гранитоидов Литинской (I) и Хмельникской (II) структур в зависимости от степени структурно-метаморфогенных преобразований пород. Ступенчатые шкалы вверху отображают степень преобразований - тектонофации (ТФ) для групп пород:

$a$ - собственно винницитов Литинской структуры, $b$ - меланократовых гранитоидов и $c$ - лейкократовых гранитоидов Хмельникской структуры на второй этап деформаций. ТФР - тектоноформации - степень преобразований для дислокационной системы. Штриховая линия - тренд температуры; пунктирно-штриховая - тренд давления

Fig. 2. P,t-values education garnets from granitoids Litynska (I) and Khmelnytska (II) structures, depending on the degree of structural and metamorphic rock transformations. Stepped top scale - reflect the degree of transformation - tektonofacies (TФ) for rock groups:

$a$ - charnockitoids of Litynska structure, $b$ - melanoratic granitoids and $c$ - leucocratic granitoids of Khmelnytska on the second stage of deformation. TФP - tektonoformation - degree of transformation for the dislocation system. Dashed line - the temperature trend; dotted-dashed line - pressure trend 
группировки положен относительный уровень мелано/лейкократовости, количество пироксена, КПШ и др.), а также по степени структурно-вещественных преобразований (ТФ). Соответственно этому размещены полученные определения $p, t$-параметров образования гранатов из них (табл. 3, рис. 2).

Оказалось, что для разных типов гранитоидов бердичевского комплекса зависимость $p, t$-значений от степени их структурнометаморфогенных преобразований разнится. Для пород групп винницитов и лейкократовых гранитоидов от наименее измененных пород к наиболее измененным $p, t$-значения увеличиваются; для пород группы меланократовых гранитоидов от наименее измененных пород к наиболее измененным $p, t$-значения уменьшаются. Для Хмельникской структуры на уровне тектоноформаций от наименее преобразованных пород к наиболее преобразованным $p, t$-значения сначала уменьшаются, а потом увеличиваются. Для дислокационной системы в целом от Литинской структуры, как относительно менее трансформированного фрагмента фундамента, к Хмельникской структуре, как относительно высокотрансформированного фрагмента фундамента, температуры уменьшаются, а давления увеличиваются.

В данной интерпретации степень перекристаллизации пород и p,t-параметры этого процесса определяются интенсивностью деформаций, скоростью, длительностью проявления во времени, кинематическими различиями деформируемых участков, количеством флюида и другими особенностями дислокационного процесса как на глубине, так и в приповерхностных условиях [Горяйнов и др., 2003; Лукієнко та ін., 2008; Паталаха и др., 1995; Слензак, 1984].

Но возможна и другая интерпретация приведенных нами данных - степень перекристаллизации во многом определяется температурой и давлением, а давление нагрузкой вышележащих пород. Чем выше эти параметры, тем более глубокую переработку испытывают первичные породы. Следовательно, чем глубже погрузилась порода и чем выше температура окружающей среды, тем сильнее степень метаморфизма. Расчетная глубина максимального погружения изученных пород составляет
10-23 км (рис. 3). Заметим, что область $p, t$-значений большинства пород как Литинской, так и Хмельникской структур располагается в районе геотермы стабильной континентальной коры, а низкобарные парагенезисы смещаются к геотерме островных дуг и зон рифтогенеза.

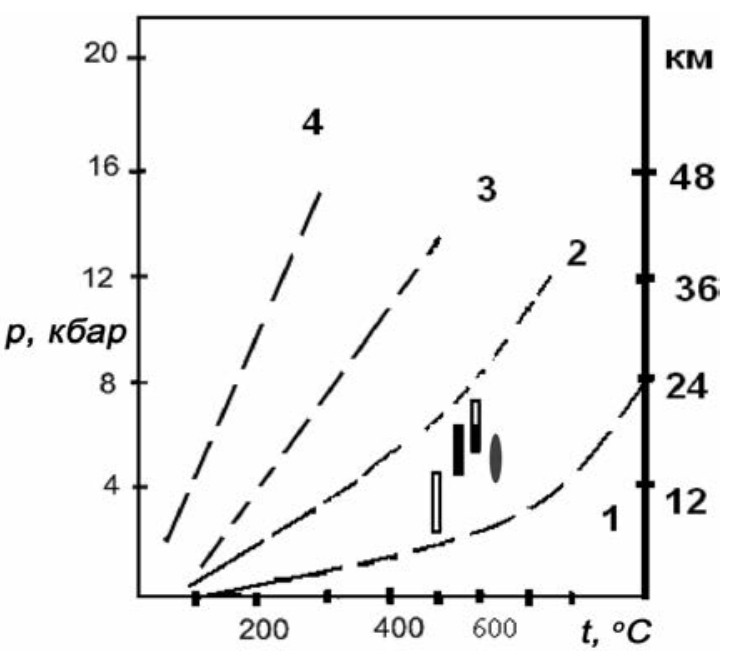

Рис. 3. Примерные области $p$, $t$-метаморфизма пород Литинской (серый овал) и Хмельникской структур (прямоугольники черные - меланократовые гранитоиды, белые - лейкократовые). Пунктиром показаны геотермы, характерные для разных геодинамических обстановок:

1 - островных дуг и горячего рифтогенеза; 2 - в пределах стабильной континентальной коры; 3 - в зоне субдукции горячей океанической коры; 4 - в зоне субдукции остывшей океанической коры

Fig. 3. Approximate area of $p, t$-metamorphic rocks Litynska (grey oval) and Khmelnytska structures (black rectangles - melanoratic granitoids, white leucocratic granitoids). The dotted line shows the geotherm characteristic of different geodynamic settings:

1 - island arcs and hot rifting; 2 - within the stable continental crust; 3 - in the subduction zone of hot oceanic crust; 4 - in the subduction zone of oceanic crust cooled

\section{Выводы}

Становление исследованного фрагмента кристаллического фундамента в пределах Днестровско-Бугского мегаблока УЩ происходило в виде дискретно проявленных и разнонаправленных существенно сдвиговых трансформаций (тектонических потоков) в четыре этапа в $p, t$-условиях образования вещества формируемых его тел. Фрагмент идентифицирован как дислокационная система вращательного сдвига. 
$P, t$-параметры образования гранатбиотитовых ассоциаций из гранитоидов бердичевского комплекса изменяются в зависимости от степени их тектоно-метаморфических преобразований:

- для групп пород собственно винницитов и лейкократовых гранитоидов от наименее измененных пород к наиболее измененным (от низких ТФ к высоким) $p, t$-значения увеличиваются;

- для группы меланократовых гранитоидов от низких ТФ к высоким $p, t$-значения уменьшаются;

- для Хмельникской структуры на уровне тектоноформаций от наименее преобразованных пород к наиболее преобразованным $p, t$-значения сначала уменьшаются, потом увеличиваются;

- для дислокационной системы - от Литинской структуры (как относительно

\section{Список литературы / References}

1. Геологическая карта кристаллического основания Украинского щита. М-б 1:500 000 / Щербак Н.П., Сторчак П.Н., Берзенин Д.З., Клочков В.М., Пастухов В.Г., Пашкевич И.К., Пияр Ю.К., Сидорова Д.А., Утробин Д.В. Киев: М-во геологии УССР, 1983. 9 л.

Geological map of crystalline basis of the Ukrainian Shield. Scale 1:500 000 / Shcherbak M.P., Storchak P.N., Berzenin D.Z., Klochkov V.M., Pastuhov V.M., Pashkevich I.K., Piiar Y.K., Sidorova D.A., Utrobin D.V. Kiev: Department Geology of USSR, 1983. 9 I. (in Russian).

2. Геохронология раннего докембрия Украинского щита. Архей / Щербак Н.П., Артеменко Г.В., Лесная И.М., Пономаренко А.Н. Киев: Наук. думка, 2005. 241 c.

Geochronology of the Early Precambrian Ukrainian Shield. Archean, 2005 / Shcherbak M.P., Artemenko G.V., Lesnaya I.M., Ponomarenko A.N. Kiev: Naukova Dumka, 241 p. (in Russian).

3. Геохронология раннего докембрия Украинского щита. Протерозой / Щербак Н.П., Артеменко Г.В., Лесная И.М., Пономаренко А.Н., Шумлянский Л.В. Киев: Наук. думка, 2008. 240 с.

Geochronology of the Early Precambrian Ukrainian Shield. Proterozoic, 2008 / Shcherbak M.P., Artemenko G. V., Lesnaya, I.M., Ponomarenko A.N., Shumliansky L.V. Kiev: Naukova Dumka, 240 p. (in Russian).

4. Гинтов О.Б. Полевая тектонофизика и ее применение при изучении деформаций земной коры Украины. Киев, 2005. 568 с.

Gintov O.B., 2005. Field tectonophysique and usage it by study deformation earth's crust of the Ukraine. Kiev, 568 p. (in Russian). менее трансформированного фрагмента фундамента) к Хмельникской структуре температуры уменьшаются, а давления увеличиваются.

$P, t$-значения отображают не окончательные условия формирования пород, а $p, t$-параметры их становления на 1- и 2-м этапах дислокационных преобразований фундамента, так как гранаты задействованы рассланцеванием генерации-2 и последующих.

Расчетная глубина образования гранатов из гранитоидов Днестровско-Бугского мегаблока составляет 10-23 км. Область $p, t$-значений большинства пород Хмельникской и Литинской структур располагается в области ниже геотермы стабильной континентальной коры, а низкобарные парагенезисы смещаются к геотерме островных дуг и зон рифтогенеза.

5. Горяйнов С.В., Денисенко Д.В., Дивицкий О.А. Метаморфические и метасоматические комплексы Среднего Побужья. Харьков: Экограф, 2003. 167 с.

Goryaynov S.V., Denisenko D.V., Divicky O.A., 2003. Metamorphic and metasomatic complexes Middlebug region. Kharkov: Ekograf, 167 p. (in Russian).

6. Державна геологічна карта України. М-б 1:200 000. Центральноукраїнська серія. Аркуш M-35-XXIII (Бердичів) / С.С. Деркач, В.Г. Зенько, С.В. Лафінчук, В.М. Павлюк, М.М. Новикова, А.В. Федоров. Київ: ПДРГП «Північгеологія», 2002. 6 л. 105 с.

State geological map of Ukraine. Scale 1:200 000. Leaf M-35-XXIII (Berdichiv) / S.S. Derkach, V.G. Zen 'ko, S.V. Lafinchuk, V.M. Pavliuk, M.M. Novikova, A.V. Fedorov. Kyiv: PDRGP «Pivnichgeologiya», 2002, 6 I., 105 p. (in Ukrainian).

7. Колесник Ю.Н., Ячменев В.Е., Вильковский B.A. Теплоемкость природных гранатов в интервале 2-300 К и энтропия твердого раствора пироп-гроссуляр-альмандин. Геохимия. 1988. № 12. C. 1798-1804.

Kolesnik Yu.N., Yahcmenyov V.E., Vilkovsky V.A., 1988. Heat capacity of natural garnets in the range 2-300 K, and the entropy of a solid solution of pyrope-grossular-almandine. Geochimiya, № 12, p. 1798-1804 (in Russian).

8. Кореляційна хроностратиграфічна схема раннього докембрію Українського щита / Єсипчук К.Ю., Бобров О.Б., Степанюк Л.М., Щербак М.П., Глеваський Є.Б., Скобелєв В.М. Київ: УкрДГРІ, 2004.

Correlational hronostratygrafic scheme of early Precambrian of the Ukrainian Shield / Esipchuk K.Y, Bobrov O.B, Stepanyuk L.M., Shcherbak M.P., 
Glevasky E.B., Skobelev V.M. Kiev: UkrDGRI, 2004 (in Ukrainian).

9. Крутиховская З.А., Пастухов В.Г., Подолянко С.М., Елисеева С.В., Неижсал Ю.Е. Исследование связи глубинных и поверхностных структур земной коры Украинского щита. Геол. журн. 1983. Т. 43, № 4 (211), С. 83-95.

Krutikhovskaya Z.A., Pastuchov V.G., Podolyanko S.M., Eliseeva S.V., Neizhsal Y.E., 1983. Study on deep and surface structures of the Earth's crust of the Ukrainian Shield. Geologicheskiy zhurnal, vol. 43, № 4 (211) p. 83-95 (in Russian).

10. Курепин В.А. Геобарометр гранат+кордиерит+силлиманит+кварц и термодинамические условия образования кордиеритсодержащих гранитов и гнейсов Украинского щита. Минерал. журн. 1998. Т. 20, № 6. С. 38-47.

Kurepin V.A., 1998. Geobarometer garnetcordierite-sillimanite and termo-dynamic conditions cordierite granite and genesis of the Ukrainian Shield. Mineralogicheskiy zhurnal, vol. 20, № 6, p. 38-47 (in Russian).

11. Лукієнко О.І., Кравченко Д.В., Сухорада А.В. Дислокаційна тектоніка та тектонофації докембрію Українського щита. Київ: ВПЦ «Київський університет», 2008. 280 c.

Lukienko O.I., Kravchenko D.V., Sukhorada A.V., 2008. Dislocation tectonics and tektonofacies of Precambrian Ukrainian Shield. Kyiv: VPC «Kyiv University», 280 p. (in Ukrainian).

12. Осьмачко Л.С., Касьяненко Е.О. О геодинамическом статусе Литинской структуры Днестровско-Бугского мегаблока Украинского щита. Modern Science. 2014. № 3. C. 86-100.

Osmachko L.S., Kasianenko K.O., 2014. About geodynamic status of Litynska structure of the Dniester-Bug megablock Ukrainian Shield. Modern Science, № 3, p. 86-100 (in Czech).

13. Осьмачко Л.С., Петриченко Е.В., Лесная И.М. О многоактности формирования березнинской толщи (на примере фрагмента Бердичевского массива) Днестровско-Бугского мегаблока Украинского щита: Тези Міжнар. наук. конф. «Геохронологія та геодинаміка раннього докембрію (3,6-1,6 млрд років) Євразійського континенту», Київ, 16-17 вересня 2014 р. Київ, 2014. С. 90-91.
Osmachko L.S, Petrychenko E.V., Lesnay I.M., 2014. About manyacteds of berezninskay thickness formation (for example, a fragment of Berdichev array) Dniester-Bug megablock Ukrainian shield: Abstracts of International scientific conference «Early Precambrian (3, 6-1,6 Ga) geochronology and geodynamics of the Eurasian continent», Kyiv, September 16-17, 2014, p. 90-91 (in Russian).

14. Паталаха Е.И., Лукиенко А.И., Гончар В.В. Тектонические потоки как основа понимания геологических структур. Киев: Феникс, 1995. 159 с.

Patalakha E.I., Lukienko A.I., Gonchar V.V., 1995. Tectonic flows as a basis for understanding the geological structures. Kiev: Feniks, 159 p. (in Russian).

15. Перчук Л.Л. Биотит-гранатовый геотермометр. Докл. АН СССР. 1967. Т. 177, № 2. С. 411-414.

Perchuk L.L., 1967. Biotite-garnet geothermometer. Doklady AN SSSR, vol. 177, № 2, p. 411-414 (in Russian).

16. Рябенко В.А. Основные черты тектонического строения Украинского щита. Киев: Наук. думка $125 \mathrm{c}$.

Ryabenko V.A., 1970. The main features of the tectonic structure of the Ukrainian shield. Kiev: Naukova Dumka, 125 p. (in Russian).

17. Слензак О.И. Локальные структуры зон напряжений докембрия. Киев: Наук. думка, 1984. $102 \mathrm{c}$.

Slenzak O.I., 1984. Local structures stress zones of Precambrian. Kiev: Naukova Dumka, 102 p. (in Russian).

18. Степанюк Л.М. Геохронологія докембрію західної частини Українського щита (архей - палеопротерозой): дис. ... д-ра геол. наук: 04.00.02. Київ, 2000. 382 с.

Stepanjuk L.M., 2000. Geochronology precambrian of the western part of the Ukrainian Shield (Archean - Paleoproterozoy). Dr. geol. sci., dis. Kyiv, 382 p. (in Ukrainian).

19. Щербаков И.Б. Петрология Украинского щита. Львов: ЗУКЦ, 2005. 366 с.

Shcherbakov I.B., 2005. Petrology of the Ukrainian shield. Lvov: ZUKTS, 366 p. (in Russian).

Стаття надійшла

08.10.2014 